\title{
Stabilization of Soil Using Flyash, Lime \& Cement
}

\author{
Santosh Dhakar ${ }^{1}$, S. K. Jain ${ }^{2}$ \\ ${ }^{1,2}$ Department of Civil Engineering, MITS, Gwalior-474005 M.P. India
}

\begin{abstract}
Black cotton soil is considered to be problematic soil as it show major volume changes due to change in its moisture content. This volume change cause wide spread damages to building and roads necessitating stabilization of such soil prior to the construction. The present paper investigates the effectiveness of different stabilizing agent viz. lime, cement and fly ash with soil for improving its engineering properties. Soil samples were collected from district Morena, in state of Madhya Pradesh, in order to look in to the relative effectiveness, and arrive at appropriate proportion of stabilizing. (1) Lime, (2) Cement, (3) Fly ash alone and combination of (1) LimeCement, (2) Cement-Fly ash, (3) Fly ash-Lime are used to stabilize the soil. Quantity of stabilizing agent varied from $2 \%$ to $10 \%$ of the soil weight and the performance is evaluated by observing variation in various engineering properties like Liquid Limit, Plastic Limit, and Plasticity Index.
\end{abstract}

Keywords: Fly ash, Lime, Cement, Liquid Limit, Plastic Limit, Plasticity Index and soil stabilization

\section{Introduction}

Deposits of expansive soil are problematic to engineering structure because of their swelling and shrinkage property. The deformations caused by swelling or shrinking are significantly greater than elastic deformation leading to large scale damage to the structure founded on such soil. The commonly observed damages are in the form of ground cracks, building cracks, falling of canal lining, heave of beds of canal, heaving and rutting of pavement etc. (Prasanna Kumar, 2011). The problem may be overcome by proper structural design but it needs expansive efforts to estimate the expected stresses in the component and subsequently designing it. The better option is to improve engineering properties of these soils by suitable stabilizing techniques. The geotechnical engineer seeks the most efficient stabilizing method considering the environment, type of structure and establish the degree of treatment needed for the structure to survive under varying soil moisture conditions. This study deals with experimental investigation for arriving at suitable solution with regards to stabilization of soil.

Yadu and Tripathi (2013) studied the soft soil of Raipur in state of Chhattisgarh, they used of Granulated blast furnace slag(GBS) and fly ash. The soil was class of CIMI as per Indian standard classification system. Different amount of GBS, viz 3\%, 6\% and 9\% with varying amount of fly ash i.e. $3 \%, 6 \%$ and $9 \%$ were used to stabilize the soft soil. The performance of modified soil was evaluated with respect to compaction and $\mathrm{CBR}$. Based on the performance of stabilized soil, author concluded that the optimum amount was $3 \%$ fly ash and $6 \%$ GBS.

Kumar (2011) carried out investigation on the two extreme types of soils viz. (1) expansive type Black cotton soil (BC Soil) and (2) non expansive type Red earth soil (RE), Nyveli Lignite Fly ash (NFA) and non pozzolanic Raichur fly ash (RFA) mixed at different doses along with supplementing additives like lime and cement were used for stabilizing the soils. The geotechnical properties like compressive strength and compaction for both soils were evaluated. The maximum dry density (MDD) of the BC soil increased from $13.6 \mathrm{KN} / \mathrm{m}^{3}$ to $15.2 \mathrm{KN} / \mathrm{m}^{3}$ for addition of $40 \%$ NFA. For R.E soil, MDD increased from 14.6
$\mathrm{KN} / \mathrm{m}^{3}$ to $17.8 \mathrm{KN} / \mathrm{m}^{3}$ for $40 \% \mathrm{NFA}$ addition. Pozzolanic fly ash resulted into considerable improvement in compressive strength. The compressive strength enhances from $310 \mathrm{KPa}$ to $1393 \mathrm{KPa}$ for B.C. soil and from 590 $\mathrm{KPa}$ to $2342 \mathrm{KPa}$ for R.E soil, for addition of $30 \%$ of NFA. MDD of BC soil increased from $13.6 \mathrm{KN} / \mathrm{m}^{2}$ to 14.2 $\mathrm{KN} / \mathrm{m}^{2}$ for addition of $40 \%$ RFA. For R.E soil, MDD increases from $14.6 \mathrm{KN} / \mathrm{m}^{2}$ to $17.4 \mathrm{KN} / \mathrm{m}^{2}$ for $40 \%$ of RFA. Addition of $3 \%$ cement to non-pozzolanic fly-ash, RFA (30\%), resulted in strength increase to four folds reaching $1317 \mathrm{KPa}$ for 28 days curing periods.

Bagui (2012) generated a chart for design of pavement using cement as a stabilizing agent for traffic upto $5 \mathrm{msa}$. As the CBR increases design thickness for cement treated base and sub-base decreases. For cement treated base thickness is $200 \mathrm{~mm}, 140 \mathrm{~mm}, 115 \mathrm{~mm}, 95 \mathrm{~mm}$ for $3 \%, 5 \%$, $7 \%$ and $10 \%$ of C.B.R value respectively. Thickness of sub-base becomes $200 \mathrm{~mm}, 150 \mathrm{~mm}, 150 \mathrm{~mm}$ and $150 \mathrm{~mm}$ for $3 \%, 5 \%, 7 \%$ and $10 \%$ of $\mathrm{CBR}$ respectively.

Hakari and Puranik (2012) uses fly ash to stabilize black cotton soil of Karnataka, India.They observed that Liquid limit and Plastic limit decreases and shrinkage limit increases with increase in fly ash content. MDD increases with decrease in OMC, CBR and UCS increases with increasing the content of fly ash. The optimum percentage of flyash is between $20 \%$ to $40 \%$.

Wu Li (2010) in his study used lime as stabilization material to stabilize the different soils from Tanzania. Author studied three types of soil viz (i) moderately plastic silty clay,(ii) moderately plastic tan clay and (iii) Heavy clay stabilized with $5 \%$ of hydrated Lime. Author designated them as $\mathrm{N}-11, \mathrm{~N}-12$ and $\mathrm{N}-13$ respectively. Plasticity Index decreases from $25 \%$ to $4 \%$ for $\mathrm{N}-11,29 \%$ to $6 \%$ for $\mathrm{N}-12$ and 36 to $9 \%$ for $\mathrm{N}-13$. Unconfined compressive strength changes from $145 \mathrm{KPa}$ to $2770 \mathrm{KPa}$ for $\mathrm{N}-11,280 \mathrm{KPa}$ to $3000 \mathrm{KPa}$ for $\mathrm{N}-12$ and 163 to $2200 \mathrm{KPa}$ for $\mathrm{N}-13$. Resilient modulus changes from $79 \mathrm{MPa}$ to $275 \mathrm{MPa}$ for $\mathrm{N}-11,53 \mathrm{MPA}$ to $63 \mathrm{MPA}$ for $\mathrm{N}-12$ and 35.8MPA to 209MPA for N-13. 


\section{International Journal of Science and Research (IJSR) \\ ISSN (Online): 2319-7064}

Index Copernicus Value (2013): 6.14 | Impact Factor (2015): 6.391

\section{Materials Used}

In this experimental study, an attempt is made to observe the effectiveness of stabilizing agents (1)Lime, (2)Cement, (3) Fly ash alone and combination of (1) Lime -Cement, (2) Cement - Fly ash, (3) Fly ash - Lime in improving various engineering properties of soil like Liquid Limit, Plastic Limit, Plasticity Index.

\subsection{Soil}

Soil of Madhogar village of district Morena in M.P. is used for this study. The soil is tested for various engineering properties like Liquid limit (L.L), Plastic Limit (P.L) and Plasticity Index (P.I). Soil has L.L 36.7\%, P.L 24.58\% and P.I 12.12\%.

\subsection{Cement}

Portland pozzolano cement (PPC) of Birla brand having $15 \%$ to $35 \%$ of fly ash is used.

\subsection{Fly ash}

Fly ash of Singhaji thermal power plant of M.P. is used. Fly ash having specific gravity 2.4 and non plastic in nature is used in work.

\subsection{Lime}

Lime locally available on shops having specific gravity 2.2 and $\mathrm{pH} 12$ is used.

\section{Test Methods for Estimation of Soil Properties}

The soil is characterized by estimating its properties viz LL, PL and PI. These properties are investigated using methods prescribed in Indian Standard codes. These tests are performed for unstabilized soil and the soil stabilized with varying quantity of stabilizing agents.

\section{Results}

The values of considered properties of unstabilized and stabilized soil are analysed in following sections to discuss the effectiveness of different stabilizing agents.

\subsection{Effect of admixture on Liquid limit of soil}

Liquid Limit of soil is $36.7 \%$. Graph 4.1 shows the effect of stabilizing agents on Liquid Limit of soil.

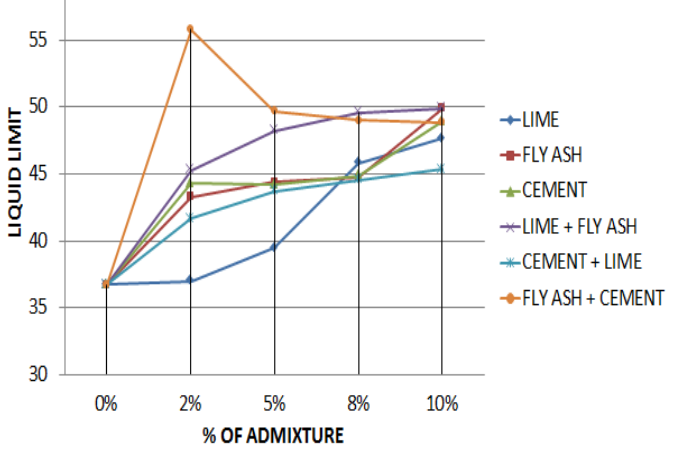

Graph 4.1: Effect of admixture on Liquid Limit of soil
The Liquid Limit of soil when lime, fly ash, lime + fly ash and cement + lime is used as admixture is continuously increases and becomes 47.63\%, 49.9\%, 49.9\% and $45.32 \%$ respectively at $10 \%$ of their content. The Liquid Limit of soil is increased at $2 \%$ of cement content then it decreases at $5 \%$ of cement content, at $8 \%$ of cement content it again increases and becomes $48.9 \%$ at $10 \%$ of cement content. The Liquid Limit of soil for fly ash + cement is continuously decreases from $2 \%$ to $10 \%$ of their content and becomes $48.85 \%$ at $10 \%$ of cement content.

\subsection{Effect of admixture on plastic limit of soil}

Plastic Limit of soil is $24.58 \%$. Graph 4.2 shows the effect of admixture on Plastic Limit of soil.

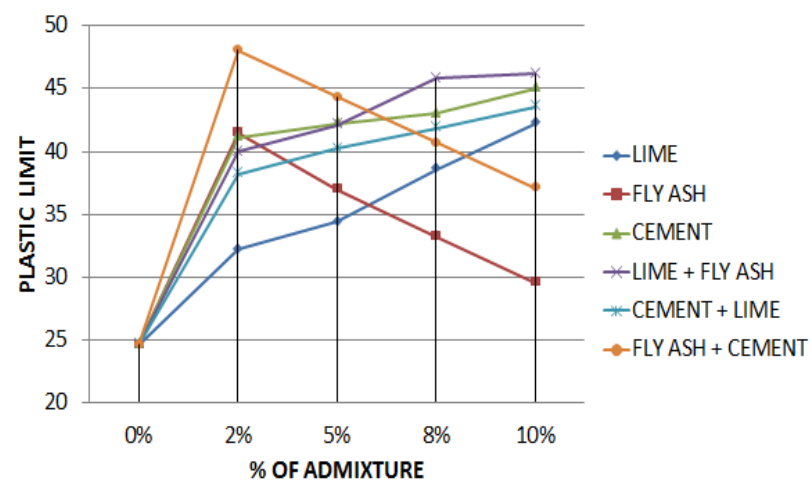

Graph 4.2: Effect of admixture on plastic limit of soil

Plastic Limit of soil when lime, cement, lime + fly ash and cement + lime is used as admixture is continuously increases to $42.21 \%, 45 \%, 46.16 \%$ and $43.55 \%$ respectively at $10 \%$ of their content. The Plastic Limit of soil for fly ash and fly ash + cement is regularly decreases to $29.58 \%$ and $37.09 \%$ respectively at $10 \%$ of their content.

\subsection{Effect of admixture on plasticity Index of soil}

Plasticity index of soil is defined as the difference of liquid limit and plastic limit. It is the measure of plasticity of soil. It is the measure of the size of the range of water content where the soil exhibits the plastic property.

Plasticity index of soil is $12.12 \%$. Graph 4.3 shows the effect of admixture on Plasticity index of soil.

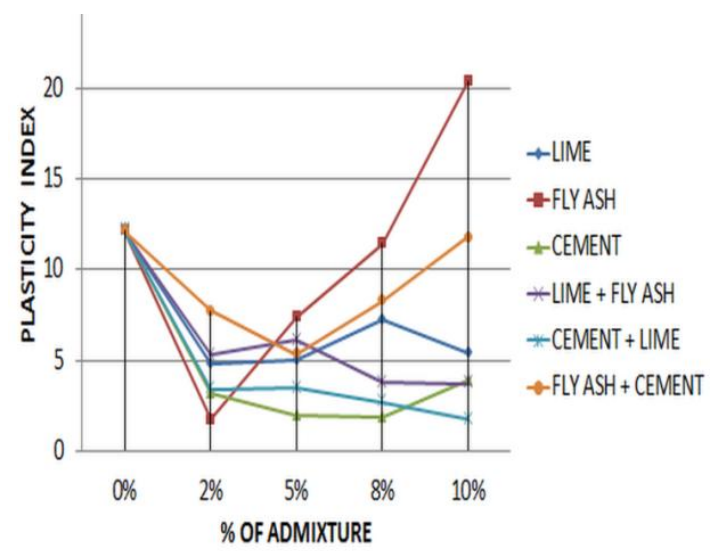

Graph 4.3: Effect of admixture on plasticity index of soil 


\section{International Journal of Science and Research (IJSR) \\ ISSN (Online): 2319-7064 \\ Index Copernicus Value (2013): 6.14 | Impact Factor (2015): 6.391}

Plasticity Index of soil for fly ash is continuously increases to $20.32 \%$ at $10 \%$ of their content. Plasticity Index of soil when lime is used as admixture is increases from $4.78 \%$ to $7.23 \%$ for $2 \%$ to $8 \%$ increase of lime content. At $10 \%$ of lime content Plasticity Index of soil is decreases to $5.42 \%$. Plasticity Index of soil is decreases from $3.3 \%$ to $1.85 \%$ for $2 \%$ to $8 \%$ increase in cement content. But for $10 \%$ of cement content Plasticity Index increases to $3.9 \%$.Plasticity Index for lime + fly ash as an admixture is increases for $2 \%$ to $5 \%$ of their content but from $5 \%$ it is regularly decreases and becomes $3.74 \%$ at $10 \%$ of their content. Plasticity Index for cement + lime as an admixture is increases for $2 \%$ to $5 \%$ of $^{i}$ their content and changes from $3.44 \%$ to $3.51 \%$ but from $5 \%$ it is regularly decreases and becomes $1.77 \%$ at $10 \%$ of their content. Plasticity Index for fly ash + cement as an admixture is decreases for $2 \%$ to $5 \%$ of their content and changes from $7.76 \%$ to $5.34 \%$ but from $5 \%$ it is regularly increases and becomes $11.76 \%$ at $10 \%$ of their content.

\section{Conclusion}

i. The liquid limit of soil increases when lime, fly ash, lime + fly ash and cement + lime is used as a admixture. When cement is used L.L is first increases then decreases and again increases. When fly ash + cement is used L.L is increases at $2 \%$ of their content and then decreases. L.L of soil is minimum for $2 \%$ of lime content. At $2 \%$ of lime content L.L of soil is $37 \%$.

ii. The plastic limit of soil is regularly increases when lime, cement, lime + fly ash and cement + lime is used as a admixture. When fly ash and fly ash + cement is used as a admixture P.L of soil is first increases then decreases. P.L of soil at $10 \%$ of fly ash content is minimum. At $10 \%$ of fly ash P.L of soil is $29.58 \%$

iii. P.I. of soil has lesser value at $2 \%$ of cement content which is $3.2 \%$. Soil having lesser value of P.I is good for engineering purposes. Hence compared to other combinations $2 \%$ of cement content is found to be more suitable.

\section{Reference}

[1] BIS (2010). "IS: 2720(part 2)-1973-Indian Standard Methods of Test for Soil, Part 2: Determination of Water Content (Second Revision)", Bureau of Indian Standards, New Delhi.

[2] BIS (2006). "IS: 2720 (Part 5)-1985-Indian Standard Methods of Test for Soil, Part 5: Determination of Liquid and Plastic Limit (Second Revision)", Bureau of Indian Standards, New Delhi.

[3] Prasanna Kumar, S.M. (2011), "Cementitious Compounds Formation Using Pozzolanos and Their Effect on Stabilization of Soils of Varying Engineering Properties", International Conference on Environmental Science and Engineering, IPCBEE, Vol. 8,pp. 212-215.

[4] Yadav, Laxmikant and Tripathi, R.K. (2013), "Stabilization of Soft Soil with Granulated Blast Furnance Slag and Fly ash", International Journal of
Research in Engineering and Technology, Vol. 02, pp. 115-119.

[5] Bagui, Swapan Kumar (2012), "Pavement Design for Rural Low Volume Roads Using Cement and Lime Treated Base", Jordan Journal of Civil Engineering, Vol. 6, pp. 293-303.

[6] D.Hakari, Udayshankar and Puranik, S.C. (2012), "Stabilization of Black Cotton Soils Using Fly Ash, Hubballi-Dharwad Municipal Corporation Area, Karnataka, India", Global Journal of Researches in Engineering Civil and Structural Engineering, Vol. 12, pp. 21-29.

[7] Fikiri Fredrick Magafu, Wu Li (2010), "Utilization of Local Available Materials to Stabilize Native Soil (earth roads) in Tanzania-Case Study Ngara", SciRP, pp. 516-519

Volume 5 Issue 6, June 2016 www.ijsr.net 